\title{
Chapter 11 \\ For Those Who Hope to Study Health, Medical Care and Welfare
}
Abstract I wrote a message for young people who are aiming to become specialists in health, medical care, and welfare.
1. Dreams are not something you can see or achieve, but something you talk about
2. Develop human resources with intelligence
3. Why do we keep learning?
4. Challenges from the unknown
5. Chance and failure create great discoveries
6. Helping one another to save lives
7. Maintenance and promotion of physical and mental functionality and nutrition
8. There may be an energetic element in food

Keywords Results-oriented approach · A world without nuclear weapons · Nobel Peace Prize $\cdot$ Humanity $\cdot$ Intelligence $\cdot$ Intellect $\cdot$ Intellectual revolution · Captain Cook · Dr. Jame Lind · Darwin · The Galapagos Islands · Jean André Dumas · Albumen · Kizuna · View of impermanence $\cdot$ Homo sapiens · Living together · Starvation experiment

\subsection{Dreams Are Not Something You Can See or Achieve, But Something You Talk About}

I believe that dreams are not just something to be seen, nor can they always be achieved, but rather they are meant to be "talk".

Our ancestors, in the midst of poverty or social instability and absurdity, 'had many dreams' and told them to many people. When reality became too severe, they had no choice but to express their dreams as stories. In recent years, however, young people have stopped talking about their dreams, and adults in particular have come to disregard dreams as fantasy and unrealistic stories. I believe that the background to this is the "results-oriented approach" that began at the end of the twentieth century. The emphasis is on planning and strategizing in such a way that final results can be generated rather than making unfounded, dream-like plans. 
The question that comes back to me when I tell my dream story is, "What do you measure outcomes by?"

The methodology of planning is to set feasible numerical targets and to work towards them. This method has been implemented in many areas because it allows us to define specific goals, to evaluate them easily, and to achieve results in a short period of time. In recent years, however, problems have emerged. This method alone does not produce long-term results, and it is difficult to draw a picture of what kind of world will be born in the end. This may be the reason why modern society is unstable, lacks an end goal, and is becoming chaotic.

I feel that times are changing and the time has come for us to "talk" about our dreams once again. It was on April 5, 2009, when I heard then U.S. President Barack Obama speak to a large crowd in Prague about his dream of "a world without nuclear weapons". He was awarded the Nobel Peace Prize, despite the fact that he was merely talking about a dream that is not feasible or achievable today. It was the first time in the history of the Nobel Prize that a Nobel Prize had been awarded for a dream with no apparent outcome.

In fact, the basis of his speech was an opinion piece published in the Wall Street Journal two years earlier by four leading American intellectuals, who argued that "we should aim for a world without nuclear weapons". They were experts who had long been engaged in U.S. defense policy, and at first, they were hesitant to publish such an unrealistic paper. However, they thought that the realization of a society without nuclear weapons should be presented as the path that human beings should take, even if it was an unrealistic story.

No matter how sick or disabled a person may be, or how old they be, or whether they have lost the use of their limbs or have lost their memory, as long as they have the will to live and the remaining functions, they can live a happy and vibrant life without being discriminated against. It may be a dream to create such a society. However, I believe that if we all talk about this dream and make constant efforts, it will come true one day. Even if we can't achieve it, I believe that if we talk about our ideal dreams publicly, people will sympathize with us, turn in the same direction, and become the driving force of a society that moves toward our ideals.

Students who have entered a vocational school or university and are about to become professionals are in the transition period of realizing not the dreams of children, but those of adults. There is plenty of time in the coming years of student life. In addition to your family, there are many people on campus who are willing to listen to your dreams, including your instructors, classmates, seniors and juniors, and people in the community. If you talk about your dream, you will give yourself the task of making it come true, and you will be able to take it seriously. Furthermore, the more you talk about your dream, even if it is a small one, the more people will celebrate with you when it comes true, the more people will grieve with you when it falls apart, and the more true friends you will make who will share your dream with you. And your life will become richer. 


\subsection{Develop Human Resources with Intelligence}

Humanity is facing some of the most difficult problems it has ever experienced, including declining birthrates, aging populations, the collapse of local environments, economic disparity, international tensions, and unknown infectious diseases. All of these issues are unavoidable for young people who aim to become professionals in the fields of health, medicine, and welfare. Moreover, each of these problems is subtly related to problems in other fields, and many of these problems are characterized by the fact that no single solution can be found. In other words, in the future, we will have to learn from past problems that have been solved, while at the same time tackling complex and diverse problems for which there is no correct answer.

Already, many experts and scholars are tackling the intractable problems posed by modern society. For example, research is underway to use cutting-edge technologies in biotechnology and robotics to change organisms themselves, and regenerative medicine to repair and reinforce malfunctioning parts. Attempts to find answers through the analysis of big data and the use of artificial intelligence in all areas of our lives to explore more efficient and rational ways of living are already being put to practical use. In 2000, Eduardo Kac, a bioartist from Brazil, had the idea of creating a fluorescent-colored rabbit as a work of art. He commissioned a French genetic engineer to do the job, and the scientists took an ordinary rabbit embryo and implanted a green fluorescent jellyfish gene into its DNA. The result was a glittering rabbit that emitted a brilliant green fluorescent color. It is only a matter of time before such technology is applied to humans, and this technology can be used not only for art but also for the prevention and treatment of diseases. However, we should not forget that such technology has the danger of creating a person who suits our preferences.

In other words, the knowledge and technology that humans have acquired through science and technology have infinite possibilities, but they also have infinite dangers. This is the kind of age we live in today.

I read a book titled "Improve Your Intellect" written by Hiroshi Tasaka. He says that it is not "intelligence" that is necessary for a doctor, but "intellect". "Intelligence" is the ability to answer questions that have answers quickly and correctly, while "intellect" is the ability to keep asking questions that have no answers. He says that the conditions for improving intellect are thought, vision, aspiration, strategy, tactics, technology, and finally, "humanity".

Intelligence can be contained in a computer, and eventually artificial intelligence will manage it. However, intellect can only be attained by learning it through one's own efforts. I think that the qualities that modern society needs in human resources are intellect that can mobilize scientific knowledge and technology, enhance innovation, and actively tackle difficult problems. Come to think of it, there is an old saying,

"That person has an intellect and is an honorable person," which is used to express high esteem, but saying someone is an 'intelligent person' is not an ethical evaluation. 


\subsection{Why Do We Keep Learning?}

People always dream for the future. Some of them are short-term plans and some are long-term dreams. In order to realize these dreams, various efforts are necessary, and the central part of these efforts is to "learn" various matters. However, it is not so long ago that people began to think systematically about the significance and methods of "learning". In the past, many people thought that it was more important to "believe" than to "learn". They believed in the teachings of God, Buddha, sages, [and] rulers, and prayed for their dreams to come true. This custom can still be seen at shrines on New Year's Day and before examinations. About 500 years ago, what is known as the "intellectual revolution" began in Europe. It was the scientific method of observing the phenomena of the world, searching for the factors and causes, discovering the laws, and using them to advance our own lives. Through this, human beings came to know the significance and value of "learning". By learning, they developed science, caused the industrial revolution in Europe, developed modern civilization, and became able to live a rational and affluent life. The reason for such an "Intellectual Revolution" in Europe lay in the preceding Age of Discovery. In those days, when European conquerors set out on a voyage, they brought aboard scholars of astronomy, geography, meteorology, botany, and anthropology, as well as sailors. In other words, conquerors not only wanted to conquer the unknown world and obtain gold, silver and treasures, but also wanted to learn new things.

The effects were first seen in the sailors themselves. Half of the seafarers died during a voyage from incurable diseases where the soft tissues of the body began to bleed, teeth fell out, wounds opened up, jaundice set in, and limbs became ineffective. Between the sixteenth and eighteenth centuries, some two million sailors died of this disease. At this time, Captain Cook of the British, following the advice of Dr. Jame Lind, gave the sailors citrus fruits, a local folk remedy of the time. As a result, the disease was completely prevented and cured. As we now understand, the incurable disease was scurvy caused by a deficiency of vitamin $\mathrm{C}$ due to the lack of fresh fruits and vegetables during the voyage. By learning how to prevent scurvy, the British were able to sail vast distances and acquired a vast amount of knowledge and data from all over the world, becoming the leaders in modern science. Similarly in physics, Newton discovered the law of the conservation of energy, and this idea led to the discovery of life energy, which became the starting point for nutrition. In biology, Darwin himself was on a voyage to South America and the Galapagos Islands, where he made observations that led to his theory. The theory of evolution made it clear that humans were not created by God, but evolved from primates that had adapted to their environment.

The origin of the fact that present society has become richer and more comfortable than before is not only because we "believe", but also because we have started to "learn", and I believe that therein lies the meaning of our continuing to learn until we die. 


\subsection{Challenges from the Unknown}

The education and training of professionals engaged in health, medical care, and welfare have been carried out mainly in technical schools. Doctors were also trained at what are called 'medical colleges'. In recent years, however, nurses, dietitians, physical therapists, occupational therapists, social workers, and others have come to seek university education, just as doctors have shifted to education at university medical schools. The progress and systematization of each discipline, which is the foundation of professional education, have led to a shift to four-year universities, as two or three years are not sufficient, and recently there has also been a call for more graduate education.

There are three main reasons for this.

The first reason is that knowledge and skills in each specialized field have become more advanced, and an educational period of two or three years is insufficient, and even four years of undergraduate education tend to be insufficient, so the need for education at graduate school has emerged.

The second reason is that at universities, students can gain knowledge and skills that are related to specialized fields and support their expertise, such as philosophy, ethics, life science, constitutional law, sociology, statistics, and languages, so-called liberal arts courses. Mastering these basic studies is essential for expanding and deepening one's field of specialization, and is necessary in today's society, where there are calls for cooperation with other fields.

The third reason is that it is essential to become aware of new methods and technology while also learning that there are things that humans do not yet know. In other words, it is necessary to study the unknown, to advance the field, and to learn that this advancement can make people healthier and happier. For 132 days from September 19, 1870, the Prussian army attacked the citizens of Paris who had risen up against the Prussian army, and Paris was besieged.

The citizens ate up all the food they had stored in their homes and began to eat cats and rats, and there was even a "cat and rat cookbook". They also went to the zoo and ate animals such as horses, elephants and lions. Inside the barricades of the besieged city, there was Jean André Dumas, who was a famous nutritionist. Seeing the people around him dying, he decided to save infants alone, and created the world's first artificial milk. It was called "Albumen," and it was made by emulsifying various proteins with oil and sweetening them with sugar.

But even after being fed this milk, the infants were dying in droves. The current knowledge of nutrition could not save the children's lives. The reason for this was that nutrition at that time only knew about carbohydrates, fats, and proteins as energy sources. Nutritionists then thought that people could live as long as they consumed energy sources. This was a tragedy caused by immature nutritional science. However, because of Dumas's seemingly reckless challenge, people learned that there were nutrients that they did not yet know about, which led to the subsequent discovery of vitamins and minerals. 
What is necessary for educators and researchers at universities is to have the humility to believe that there are unknowns in academia, the courage to try to learn about them, and the interest to continue investigating.

\subsection{Chance and Failure Create Great Discoveries}

Lately, I've been worrying about something.

That is, thanks to the advancement of IT technology, if you enter a keyword on your computer or smartphone, the machine will search for it and give you the answer instantly. If you become accustomed to this way of accessing information, you may mistakenly believe that every problem or issue has a correct answer and that you can easily get it if you just enter the keyword.

Before the development of IT, if you did not understand something, you had to ask the opinion of a teacher or an expert, spend time in the library, read all the relevant literature and books, and think about it. We had to think about this and that to get the answer. Scientists spent a lot of time, made repeated mistakes, and twisted and turned to get the answer. The answer may have been incomplete, inadequate, or incorrect. However, because I had spent so much time and effort to obtain the answer, I was satisfied with it and it was persuasive to others. In addition, in the process of deriving answers, I sometimes made unexpected discoveries by searching wrongly or looking wrongly. Recently, our country has been producing a Nobel laureate every year. The story that often comes out from the laureates is that if you keep challenging yourself, you will make great discoveries, but the process requires chance and failure. Trying to seek answers by the usual means that most people use will only yield the usual answers. It is through these seemingly futile challenges that we encounter chance and failure, and it is in the persistent search for the cause that new discoveries are made.

When you are a student, the more you learn, the more things you don't understand, and the more you stop, get confused, and worry. However, we must not forget that this is what will help us grow as human beings and professionals. I believe that the reason why human beings have evolved remarkably as intelligent animals compared to other animals is not only because we have evolved by adapting to our biological environment, but also because we have a strong will and the courage to learn about the unknown and to try to lead a better life, as well as the ability to take on new challenges.

\subsection{Helping One Another to Save Lives}

The twenty-first century began with the end of high economic growth, serious environmental problems, and an era in which humanity was searching for a new set of values and a new social framework. Then, on March 11, 2011, the Great East 
Japan Earthquake struck. The science that had built our affluent society could not have foreseen the disaster, and nuclear power, which had brought together the best of science and technology, instantly became a high-risk energy source. However, in the midst of this darkness, we have found a ray of light in "kizuna". The word "kizuna": bond comes from the Chinese character for "tazuna", a yoke which is used to keep animals together, and means a bond between people that cannot be separated.

In particular, the Japanese archipelago is an inherently unstable land, and we are hit by typhoons every year, and have experienced many major earthquakes. Each time, our peaceful daily lives have been destroyed, and we have lost many people who are indispensable to us. Japanese people have always had a "view of impermanence" as their outlook on life, believing that there is no such thing as "normal" in this world and that things are fleeting. In the process of destruction, they cherished the bonds among people, and in the process of reconstruction, they improved their knowledge and skills and nurtured the spirit of helping one another.

Furthermore, we should not forget that people from all over the world offered their hands of support after the earthquake. The spirit of helping one another in times of trouble is not unique to the Japanese, but is common to all human beings. So, why did only humans have this kind of heart? As a matter of fact, chimpanzees are also said to give a piece of stick to help another chimpanzee who cannot reach a banana. But the chimpanzees, both the one that helped and the one who was helped do not have any feelings about it, they are not grateful for the help, and they do not return the favor on any occasion.

Recently, traces of Homo sapiens, the ancestor of modern humans, were discovered in the Blombos Cave near Cape Town in the southernmost part of Africa. In fact, a tribe with those genes still lives in the village of Mahamasi in the Kalahari Desert. There, food from hunting is limited, so they follow the basic principle of sharing everything with everyone, whether the harvest is good or bad. If a village suffers from hunger, a nearby village will always help, and the village that is helped will give away a lot of milk the following year, thus establishing a mutually beneficial relationship. Those who would not establish such a relationship were driven out of the village and could no longer survive on their own. In the end, only those humans who were able to establish a relationship of mutual help survived, and it is believed that the spirit of "living together" of modern humans was created in this way.

Health, medical, and welfare professionals are professionals who aim to improve people's health and happiness, and it is important to provide care that is close to the human heart. At Kanagawa University of Human Services, new students are immediately given practical training at a neighboring site in collaboration with four departments. Initially, there were various opinions about sending new students, who had no specialized knowledge or skills, out into the field. However, we believed that it is necessary for professionals who provide care for people to improve their sensitivity as human beings in order to be close to people, and that this can be learned through actual experience. In addition, we wanted the students to learn the necessity of multidisciplinary cooperation by forming a team of four departments. 
Many students come into contact for the first time with people suffering from incurable diseases, people who were born with mental or physical disabilities, and people who are still trying to live every day. At first, they do not know how to talk to them, and cannot hold their hands or speak to them. This is because today's young people, who have grown up in nuclear families, do not have the experience of witnessing the moment when a person is born or dies, and they rarely see the reality of a person growing old and falling ill. However, becoming a health, medical, or welfare professional means confronting the reality of life, including aging, illness, and death, which can be said to be the fate of human beings.

After the practical training is completed, a presentation is given in the classroom. Many of the students tear up and talk about how moved they are to have a relationship with the sick and disabled that allows them to talk and touch them. I believe that this sensitivity is the key to sustaining and developing this profession.

\subsection{Maintenance and Promotion of Physical and Mental Functionality and Nutrition}

In order to extend healthy life expectancy, it is necessary to prevent the onset and exacerbation of diseases. And as people age, avoidance of long-term care becomes more important, and the main focus of frailty prevention. At the heart of frailty prevention is the prevention of undernutrition. Typical diseases include energy and protein deficiency, iron deficiency anemia, and osteoporosis due to calcium deficiency. In particular, the elderly suffer from a low-nutritional state in which both energy and protein are insufficient. This is due to a decrease in the intake of fats and oils, meat, milk and dairy products, and eggs, as the elderly generally eat smaller meals and prefer lighter foods. In the elderly, the body's ability to synthesize protein and recover it is also reduced. When energy intake is insufficient, the breakdown of body fat and muscle increases to compensate, resulting in a loss of body weight and muscle mass. This, combined with the decreased ability of the liver to synthesize protein due to old age, is characterized by a decrease in protein (albumin) in the blood.

To what extent do people lose their physical and mental function due to undernutrition?

The decline in physical and mental functioning observed in clinical practice is generally due to the effects of disease and cannot be said to be purely due to nutrition. In order to observe this in an absolute sense, it would be necessary to conduct an experiment of undernutrition in healthy people, a so-called "starvation experiment" which is ethically impossible. However, in 1944, during the war, the "Minnesota Starvation Experiment" was conducted in the United States. The public was invited to participate in the experiment, and for six months, caloric intake was reduced to $1570 \mathrm{kcal}$ per day (half the normal intake), and exercise was limited to walking $35 \mathrm{~km}$ per week. 
Table 11.1 Psychological changes observed with undernutrition

\begin{tabular}{l}
\hline Decreased ability to concentrate, pay attention, grasp, and make judgments \\
\hline Increased mental fatigue \\
\hline Helplessness and lack of emotion increased \\
\hline Interest in the opposite sex and decreased sexual desire \\
\hline Addiction to gum and coffee \\
\hline Increased mood disturbances, fickleness, and irritability \\
\hline Depression, hysteria \\
\hline Impatience and frustration developing into angry outbursts \\
\hline Increased nervousness and anxiety \\
\hline Nail biting, smoking \\
\hline Lack of hygiene \\
\hline Suicide planning and self-harm \\
\hline Withdrawal, isolation, lack of humor and fraternity \\
\hline Shoplifting
\end{tabular}

As a result of the experiment, the average body weight went from 69 to $52.4 \mathrm{~kg}$ $(-16.6 \mathrm{~kg})$. In addition, physical changes occurred, such as a decrease in body temperature and pulse rate, decreased physical strength, edema, and decreased vision and hearing. Noteworthy were the mental changes such as decreased concentration and attention, depression, irritability, apathy, and hysteria (Table 11.1). These symptoms are often observed in elderly people. In other words, the decline in mental and physical functions is caused by low nutrition, regardless of disease, and the improvement of nutritional status can maintain and improve the mental and physical functions of the elderly to some extent.

\subsection{There May Be an Energetic Element in Food}

For a long time, I knew I didn't want to get pancreatitis. I had been told by those who had experienced this disease how painful the onset was. In the middle of July 2019, I was hospitalized for 10 days because of severe pain. I usually drink a glass of beer or so, but I got carried away and drank too much because I was enjoying talking with friends at a dinner party and also because good sake was being served. The diagnosis was "alcoholic acute pancreatitis". I had to drink and eat nothing by mouth for a week.

Through three catheters, anti-inflammatory drugs, antibiotics, and nutritional supplements began to be administered. This is the so-called spaghetti syndrome. Three liters of $5 \%$ dextrose infusion were administered per day, so the carbohydrate intake was 150 grams and the energy level was $600 \mathrm{kcal}$. This amount is about half the basal metabolic rate of a healthy person, and because of the inflammation, energy consumption is high, and even if adequate fluids, vitamins, and electrolytes are administered, there is a significant energy deficit. During this period, the breakdown 
of body fat and protein increases to compensate for the lack of energy and carbohydrates, so my weight at discharge from the hospital had decreased by $3 \mathrm{~kg}$. However, this is the limit of peripheral intravenous nutrition, and even if it is administered for $24 \mathrm{~h}$, a state of energy deficiency cannot be avoided, and there is no administration of amino acids or essential fatty acids. What is important is the nutritional support during recovery.

To tell the truth, strangely enough, not being able to eat was not as hard as I had imagined when I was healthy. It was partly because the intravenous drip kept my blood sugar up and I didn't feel hungry, but all I had to do was walk three meters to the bathroom to urinate, and the rest of the time I just slept and didn't feel any inconvenience because I didn't feel or think anything. I thought that if I continued like this, anyone could enter a "vegetative state", in the usual phrase.

Perhaps it was because I had been well nourished before, but I recovered remarkably quickly, the inflammatory reaction decreased, and I started eating with a soft diet. A soft diet is an easy-to-digest diet containing lots of water.. As I began to feel the delicious taste of food in my mouth and the desire to eat, I began to feel energized and had the strength to try to live. In other words, I went from plant to animal again. It's not that my nutritional intake had been met, my weight had increased, or my albumin had risen. Just being able to eat and taste through my mouth gave me the energy to live positively.

This experience was a good opportunity for me to think about nutrition and food in the future. Since being discharged from the hospital, I have been grateful for being able to eat normally three times a day, as much as I like.

Open Access This chapter is licensed under the terms of the Creative Commons AttributionNonCommercial-NoDerivatives 4.0 International License (http://creativecommons.org/licenses/bync-nd/4.0/), which permits any noncommercial use, sharing, distribution and reproduction in any medium or format, as long as you give appropriate credit to the original author(s) and the source, provide a link to the Creative Commons license and indicate if you modified the licensed material. You do not have permission under this license to share adapted material derived from this chapter or parts of it.

The images or other third party material in this chapter are included in the chapter's Creative Commons license, unless indicated otherwise in a credit line to the material. If material is not included in the chapter's Creative Commons license and your intended use is not permitted by statutory regulation or exceeds the permitted use, you will need to obtain permission directly from the copyright holder. 